\title{
The Factors Affecting Innovative Activities and Cost Management
}

\author{
Irina Karakozova ${ }^{1}$, and Yulia Prokhorova ${ }^{1, *}$ \\ ${ }^{1}$ Moscow State University of Civil Engineering, 129337 Yaroslavskoe shosse 26, Moscow, Russia
}

\begin{abstract}
The article presents general and specific factors that influence the generation and management of facility construction cost. It is suggested to create a national information system for costs formation in construction that would correspond to the current requirements of a dynamic requirements. Efficiency of the proposed methods shall be ensured by increased accuracy of estimates at the phase of investment decision taking for any public capital investments, from direct budgetary expenditure to extra-budgetary funds resources, subsidies and grants.
\end{abstract}

\section{Introduction}

Within the past few years, along with the reputable practice-oriented approaches to construction cost formation, Russian economy has witnessed a gradual implementation of cost-oriented approach and cost engineering methods into management practices. In the broadest terms, their fundamental nature lies in determining and systematizing cost aspects of management activities within an enterprise or of project realization. However, academic and methodological literature on these issues, especially practically oriented one and applicable to the construction sector in the Russian Federation, is currently insufficient [14]. In the context of a politically and economically unstable situation, the importance of management for facility construction costs with support from federal budget is increased, because the issues of rational resource saving, efficient assets operation, and project realization in general become a priority at any level, starting from the state one to the level of separate companies and investment projects [5-6].

Construction sector is one of the key catalysts for economic growth in the Russian Federation. Public procurement for construction and installation activities accounts for 40 $\%$ of total volume, and it is expected that in the nearest years, the Russian Federation government shall invest several trillions of rubles into the upgrade and amplification of the country's infrastructure [1].

Construction sector plays an essential role in Russian economy, and the condition thereof is an indicator of economic and technological development of the state. However, there exists a series of external circumstances that "slow down" the income-generating sector of the country, and first of all, one should name rather low quality of facility engineering and construction as such. An important obstacle lies in the absence of a proper

\footnotetext{
*Corresponding author: eshly.06@mail.ru
} 
basis for regulatory documents, updated and revised in accordance with the latest technological and technical amendments and decisions [3]. As far as the application of regulatory methodological documents to costs formation and costs estimate is being concerned, current situation is equally complicated.

The Minister of Construction Industry, Housing and Utilities Sector of the Russian Federation, M.A. Men, commissioned this issue to the Supervisory board of the federal autonomous organ called Federal center for cost formation in construction and construction materials industry, which approved strategic directions for its activities in 2016-2020 aimed at implementation of the Reform Philosophy for Cost Formation and Cost Estimate in Construction Industry. By 2020, the technological strategy of the reform implementation should result in elaboration of new national regulatory estimate basis, updated methodological guidelines, indications and manuals, new reference books of state estimate standards and quotations, and in development of a national information system (NIS). But the regulatory basis as such does not resolve the issue of interaction of the concerned parties during implementation of an investment construction project with regards to quality, terms, and costs, because engineering companies are normally directly dependent on the customer and are obliged to comply with his specific requirements, while the customer is often only driven by "optimization" of his own expenses [7-15].

\section{Methodology}

\subsection{Complex cost management}

There is a practical necessity to increase competitiveness of construction companies through expert assessment of civil construction costs in order to justify feasibility, volume and terms of capital investments. And this implies elaboration of a universal standard for managing facility construction cost, i.e., a basis that would allow a specific company to create its own costs managing system, while accounting for financing particularities and properties of the facility under construction[13].

The issues of complex cost management for investment projects at different life cycle stages are investigated in a number of studies by foreign authors, such as Larry R. Dysert, Williams Jr. R., Chilton C.H., Guthrie K.M., Remer D., Chai L., Vatavuk W.M., Hall Richard S., Lang H.J., Miller C.A., Hand W.E., Black J.H., Dysert L.R., and others, and their works served as the basis for the integrated approach to portfolios, programs, and projects management within the complex cost management.

However, the critical analysis of foreign studies revealed insufficient development of methodological issues in forming an innovative organizational and economic mechanism for managing facility construction costs on the basis of cost engineering methods, the reason for this being the absence of a universal approach to the construction cost management system, to the problem of analysis and synthesis for requirements and construction cost management indicators, to the issues of elaborating a conceptual model and estimating final efficiency.

In Russian practice, project cost management implies a sequence of planning processes applicable to resources that are required for project execution, estimation of their costs, formation of total costs for each cost item, and controlling the cost of the project throughout all stages of its execution.

Consequently, project financing is based on two documents: project estimate and project budget. Project estimate represents a structured list of expenses and income per cost item and per project sections, while project budget provides information on expenses and income items distribution with reference to time periods[7]. 
Russian experience of cost management is described in works by such authors as Reznichenko V.S., Lenintsev N.N., Dorozhkin V.R., Didkovskaya O.V., Kuzminsky A.G., and others [6].

Analysis of their studies reveals existing problems in cost estimates and cost formation related to issues of retrieving complete and true estimated expenses due to the lack of modern system for regulatory estimation standards used at different stages of an investment construction project, constant monitoring of resources prices, description of methodological approaches to estimated cost calculation in facility construction while preparing FEED, project, bid, and other documentation.

Besides, yet another problem is revealed: lack of an efficient marketing system for vendors selection based on a system for monitoring market prices in construction products (buildings, structures) [5].

If the complete life cycle of a project is considered from the point of view of expenses estimation, then at each stage we can see various types of assessment, from enlarged to more detailed ones.

This objective implies recurring to such methods of project cost estimation as parametric project cost estimation, estimation by equivalent facilities, estimation on the basis of bid proposals from potential contractors, "downward" estimation, "upward" estimation, and so on.

Depending on the project phase, on the established objective, on the evaluation method and on the resulting estimate document, Russian experience of project cost management comes up with error within the range of $0 \ldots 40 \%$. At the same time, selected method depends on specific project, on contractor's qualification, on availability and quality of a hierarchical structure of works, on degree of accuracy assumed in calculations, etc. [3].

It is well known that abroad, the majority of construction contracts, both public and corporate ones, are awarded through bids. In this case, the Customer prepares such documents, among others, as an Invitation for bid, a Request for proposal, a Request for quotation, but not the Contract price.

These documents usually contain a detailed list of activities and their scope of works, and they should be flexible enough to incorporate the contractors' capabilities to improve the proposed contract conditions.

That is why totally different approaches to construction cost estimation are applicable for the investor and for the contractor: while the investor makes an approximate estimation of required financing for the construction in general, the contractor calculates with much more detail production costs and quotations for the specific range of works to be provided [14].

In contrast to the foreign experience, contemporary cost formation in Russian construction sector tries to apply the same method to different tasks, while using unit costs, which provokes reasonable criticism both from the investors and public customers, and from the contractors. The customer is unable to determine the contract price without preparing project, or better still, working documentation, and making detailed estimate calculations, while the contractor is unable to accurately calculate the quotation on the basis of the estimates that are inevitably averaged.

As construction contractors should meet specific requirements that differ from the conventional financial evaluation criteria, for example, from the investor's (customer's) point of view, a specific methodology is required.

This methodology should analyze and synthesize conventional financial and other factors applicable to construction companies' activities, and would allow classifying contractors by their capability to perform within a certain scope of works within the construction process [10]. 
Thus, we might conclude that the organizational and economic mechanism for managing facility construction costs should be generated individually for each participant of the investment-construction process as a system where its objectives are being formed, and tasks aimed at achieving these objectives, and stimuli that allow revising its spiritual, environmental, social and material needs during the project execution, accounting for the final result oriented at the satisfaction of consumer's demand for this particular product.

\subsection{Organizational and economic mechanism for managing facility construction costs}

Organizational and economic mechanism might be structurally represented as an aggregate of three systems: target, information and functional ones.

A target system should comprise objectives and main performance indicators for investment and construction projects, as well as selection criteria and progress evaluation and results assessment criteria.

An information system is required in order to provide updated, complete and true information for all stages of operation within the mechanism being developed. It includes subsystems for providing legal, resource, regulatory technical, regulatory methodological and research information.

A functional system is oriented at consecutive resolution of tasks being set at the stages of planning, organizing, controlling, and creating/improving a database.

Efficient use of public investment requires creation of an updated regulatory legal and methodological basis for the domain of costs formation and costs estimates, that would ensure the balance of interests for all parties involved in the construction process, unity of approaches and methods for estimation and monitoring of construction products costs for all levels of public authorities, ministries and state organs, extended application of information systems, analytical software packages [2].

Number of subsystems within each system might vary, in accordance with the type and the scale of the facility under construction, with the number of participants in the respective investment and construction process, effect level of the external environment, and internal preparedness of the contractor [12].

Together with structural development of the organizational and economic mechanism for managing facility construction costs, we should define its principles of operation applicable when managing decisions in this domain are being taken and executed. Among the basic principles one might name the following: principle of innovation, principle of consistency, principle of adaptability, principle of business ethics, principle of reliability, principle of expenditure justification, etc.

The principle of innovative operation within the cost management system implies that all participants of an investment and construction process are oriented towards innovations and aspiring to discover new opportunities.

The principle of consistency implies an aggregate of all systems and subsystems within the certain area, accounting for the influence of external factors, in order to achieve the preestablished objective.

The principle of adaptability aims to provide timely reaction of all participants, accounting for current changes in external and internal environment. The principle of business ethics implies open and transparent relations between the process participants in their interactions with each other. The principle of reliability is intended to create conditions that would ensure uninterrupted system operation in the context of limited resources.

The principle of expenditure justification suggests selection of an efficient and transparent tool for costs calculation in order to obtain true and non-prejudicial cost for 
facility construction. Such principles allow integrating the organizational and economic mechanism for managing facility construction costs into the general management system applicable in the specific construction company [8].

Creation of the organizational and economic mechanism for managing facility construction costs shall include the following consecutive phases:

- analysis of development and of internal state of the company;

- external environment analysis;

- gathering information on previously constructed facilities (performed works) with the use of the database on contract (subcontract) construction companies, analysis of the obtained results, preparation of proposals for modifications of functional connections between elements of the costs management system, should any deficiencies be revealed within its structure;

- evaluation of a possibility to improve managing system for facility construction costs (certain scope of works cost) in the domain of development and further application of an efficient organizational and economic mechanism for costs management based on cost engineering methods (Figure 1)

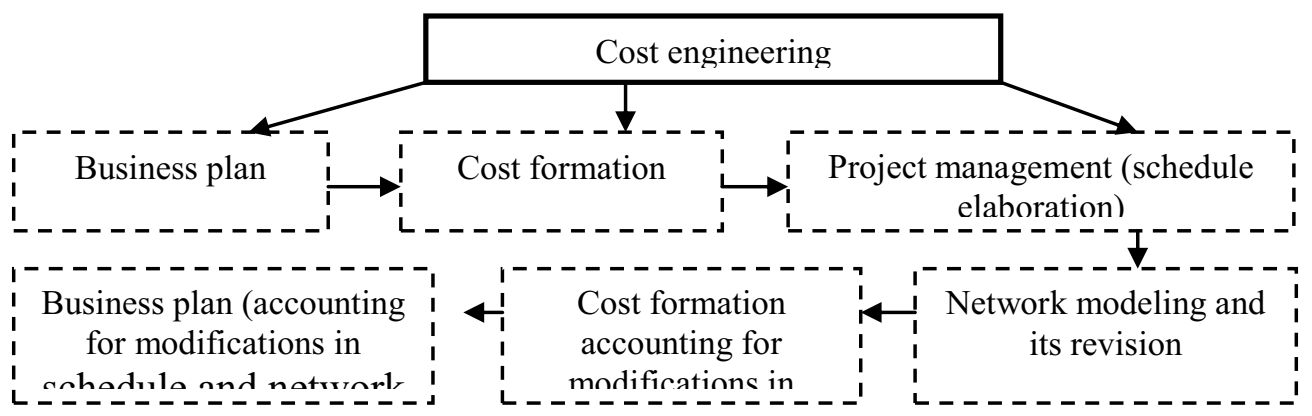

Fig. 1. Cost engineering.

- preparing a program of measures aimed at creation/improvement of the organizational and economic mechanism for managing facility construction costs, including a list of activities, distribution of required resources and responsibilities for measures implementation;

- implementation of measures aimed at creation / improvement of the organizational and economic mechanism for managing facility construction costs, evaluation of the obtained performance results, database update.

\subsection{Cost formation for the facility construction}

The organizational and economic mechanism for managing facility construction costs is based on the fundamental economic concepts, where the cost of a construction product is a calculated cost at the specific moment of time, expressed in monetary equivalent. At the same time, the costs for the contractor are usually higher than the costs calculated by economic methods and accounting for the customer's perspective.

It is therefore absolutely obvious that the facility construction costs shall be formed gradually at different stages of the investment process, accounting for interests of both the customer and the contractor (Table 1).

Which means that approaches to determining estimated facility costs shall be classified in accordance with stages of the investment and construction project and with accuracy level of the resulting estimates [17] 
Table 1. Costs formation at different stages of the facility construction.

\begin{tabular}{|c|c|c|c|c|}
\hline Contents & $\begin{array}{l}\text { Approach } \\
\text { to cost } \\
\text { formation }\end{array}$ & $\begin{array}{l}\text { Methods of costs } \\
\text { formation }\end{array}$ & $\begin{array}{l}\text { Sources of } \\
\text { information }\end{array}$ & Required basis \\
\hline \multicolumn{5}{|c|}{ Pre-investment phase } \\
\hline $\begin{array}{l}\text { Preliminary costs } \\
\text { estimation }\end{array}$ & $\begin{array}{c}\text { Income- } \\
\text { based; } \\
\text { Comparative }\end{array}$ & $\begin{array}{l}\text { Direct capitalization; } \\
\text { Discounting for future } \\
\text { cash flows; } \\
\text { Direct comparison; } \\
\text { Comparison by } \\
\text { analogy; } \\
\text { Targeted corrections; } \\
\text { Development of } \\
\text { statistic models; } \\
\text { Specific technical and } \\
\text { economical indicators }\end{array}$ & Draft solutions & $\begin{array}{l}\text { Nation wide automated } \\
\text { information and reference } \\
\text { system, allowing } \\
\text { accumulating and } \\
\text { integrating information on } \\
\text { the cost, technical, } \\
\text { economical and structural } \\
\text { specifications of the } \\
\text { constructed facility on the } \\
\text { performed contract bidding } \\
\text { as it pertains to contract } \\
\text { price, and allowing } \\
\text { convenient search of } \\
\text { information ensuring its } \\
\text { availability and } \\
\text { transparency }\end{array}$ \\
\hline \multicolumn{5}{|c|}{ Investment phase } \\
\hline $\begin{array}{c}\text { Stage } 1- \\
\text { preparation of } \\
\text { cost estimate } \\
\text { documentation } \\
\text { (development of } \\
\text { estimated cost of } \\
\text { construction - } \\
\text { investor's } \\
\text { (customer's) } \\
\text { price) }\end{array}$ & $\begin{array}{c}\text { Expenditure- } \\
\text { based }\end{array}$ & $\begin{array}{l}\text { Base-index based; } \\
\text { Aggregated cost } \\
\text { estimation; } \\
\text { Analogue-parametric }\end{array}$ & $\begin{array}{c}\text { Project } \\
\text { documentation, } \\
\text { work scope } \\
\text { data, customer's } \\
\text { data base on the } \\
\text { cost of } \\
\text { completed } \\
\text { projects }\end{array}$ & $\begin{array}{l}\text { Modern system of cost } \\
\text { estimation regulations with } \\
\text { aggregation according to } \\
\text { consolidation degree and } \\
\text { application level, database } \\
\text { on completed construction } \\
\text { projects }\end{array}$ \\
\hline $\begin{array}{l}\text { Stage } 2 \text { - bidding } \\
\text { (arrangement of } \\
\text { offer - } \\
\text { contractor's } \\
\text { price) }\end{array}$ & $\begin{array}{c}\text { Expenditure- } \\
\text { based }\end{array}$ & $\begin{array}{l}\text { Base-index based; } \\
\text { Resource-based; } \\
\text { Resource-index based; } \\
\text { Aggregated cost } \\
\text { estimation; } \\
\text { Analogue-parametric }\end{array}$ & $\begin{array}{l}\text { Cost estimate } \\
\text { documentation, } \\
\text { construction } \\
\text { work scope } \\
\text { information } \\
\text { provided by } \\
\text { customer; } \\
\text { contractor's } \\
\text { data base on the } \\
\text { cost of } \\
\text { resources } \\
\text { required for a } \\
\text { single unit of } \\
\text { work } \\
\end{array}$ & $\begin{array}{l}\text { Modern system of cost } \\
\text { estimation regulations with } \\
\text { aggregation according to } \\
\text { consolidation degree and } \\
\text { application level, } \\
\text { contractor's database on } \\
\text { the cost of works } \\
\text { considering adjustment } \\
\text { factors, establishing of } \\
\text { analytical institutions } \\
\text { developing adjustment } \\
\text { factors for contractors. }\end{array}$ \\
\hline $\begin{array}{c}\text { Stage } 3- \\
\text { preparation of } \\
\text { contract price } \\
\text { and finalization } \\
\text { of agreement } \\
\text { with successful } \\
\text { bidder. }\end{array}$ & - & $\begin{array}{l}\text { Fixed contract price } \\
\text { with application of } \\
\text { compensatory } \\
\text { arrangements for } \\
\text { adjustment of the } \\
\text { finalized price, } \\
\text { considering } \\
\text { customer's and } \\
\text { contractor's interests } \\
\end{array}$ & $\begin{array}{l}\text { Design and cost } \\
\text { estimate } \\
\text { documentation }\end{array}$ & $\begin{array}{l}\text { Modern system of cost } \\
\text { estimation regulations with } \\
\text { aggregation according to } \\
\text { consolidation degree and } \\
\text { application level, predicted } \\
\text { indices of construction cost } \\
\text { escalation. }\end{array}$ \\
\hline $\begin{array}{c}\text { Stage } 4- \\
\text { settlements } \\
\text { between } \\
\text { customer and } \\
\text { contractor within } \\
\text { the agreed cost }\end{array}$ & - & $\begin{array}{l}\text { Payments for the } \\
\text { performed packages } \\
\text { (stages) of works or } \\
\text { completion percentage } \\
\text { of the constructed } \\
\text { facility. }\end{array}$ & $\begin{array}{l}\text { Construction } \\
\text { contract }\end{array}$ & $\begin{array}{l}\text { Recommended reference } \\
\text { procedure of designation of } \\
\text { packages (stages) of works } \\
\text { and procedure of } \\
\text { determination of } \\
\text { percentage of each stage } \\
\text { within the total cost of the } \\
\text { entire facility }\end{array}$ \\
\hline
\end{tabular}


This staged approach to construction cost formation allows facilitating state supervision of cost formation and utilization of federal funds. This raises the possibility of replacing fiscal punitive measures (fines, sanctions), with economical and preventive depending on:

- relevance and correctness of selection of initial (maximum) contract price;

- conformity of payments for construction works with the posted price;

- degree of completion of the paid stages (packages) of works;

- quality and consumer properties of completed works (raising responsibility of technical, state and designer's supervision).

Preparation of efficient economical and organizational scheme of construction management allows handling the problems of cost formation and planning of capital investments, cost management and formation of company's investment policy. To achieve this, a single information space must be created allowing flexible and timely response for changes and for management decisions with due consideration of external factors and internal condition of the company. Therefore, organizational and economical scheme of construction cost management provides a new format for interaction between the participants of construction project and for estimation of the costs of upcoming construction project.

\section{Key findings}

Academic aspect of challenges related to construction costs management addresses the issues of methodological approach development which would allow determining an algorithm for efficient expenditure accounting during facility construction based on budgetary allocations.

Performed studies and theoretical justifications in this direction lag behind the present day reality, and need further development. Important of the covered issue results from nonavailability of innovative model allowing handling all challenges related with cost engineering of capital construction timely and accurately.

Performed analysis allows generating a model of the organizational and economic mechanism for managing facility construction costs.

True-to-life determination of the estimated costs for construction (reconstruction, extension, modernization, overhaul) of buildings and structures remains one of the main directions for costs estimates and costs formation system reform, that is currently being executed in the Russian Federation.

Due to specific particularities of the construction industry, when costs estimates should be approved long before the facility construction starts, construction professionals have to justify the future expenses with a large margin for error.

Besides, this process is additionally complicated by the imperfection of effective costs estimate regulations that are not completely suitable for strategic estimations and are more oriented at calculations for separate components on the basis of the working documentation. In order to perform a true and accurate estimation of a future facility construction costs, prior to engineering activities, a whole complex of enlarged regulations shall be applied, presenting costs for construction solutions distributed by type of facility or by scope of works [18]. (Figure 2) 


\begin{tabular}{|c|}
\hline Target system \\
\hline Purpose of the facility \\
\hline Business planning \\
\hline Production cycle duration \\
\hline $\begin{array}{l}\text { Quality indica tors for } \\
\text { construction and installation }\end{array}$ \\
\hline $\begin{array}{l}\text { Adaptability and flex ibility of } \\
\text { project m anagem ent }\end{array}$ \\
\hline $\begin{array}{l}\text { Contents and structure of } \\
\text { financing sources }\end{array}$ \\
\hline $\begin{array}{l}\text { System of indicators that } \\
\text { influence the facility } \\
\text { construction costs }\end{array}$ \\
\hline
\end{tabular}
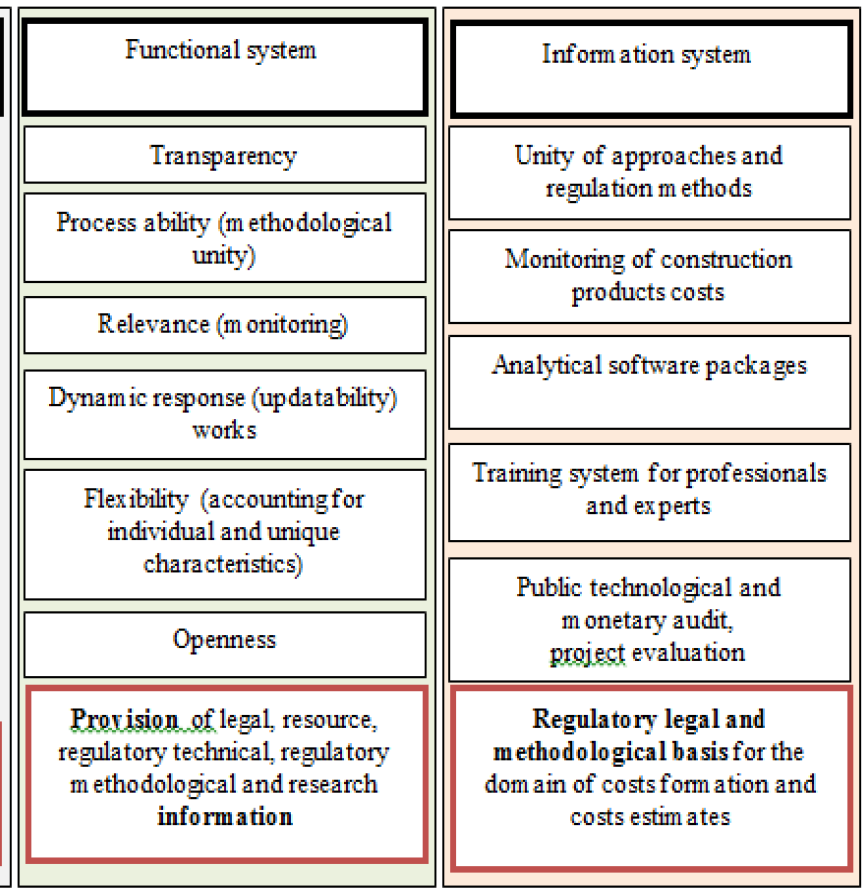

Fig. 2. Model of the organizational and economic mechanism for managing facility construction costs.

Development of methodological bases and detailed approaches to development of enlarged estimates regulations shall allow determining construction costs estimate according to existing circumstances of operations and to market economy relations in action. Under current market conditions, new concept of estimated costs formation shall be oriented at producing new methodological approaches to operation of enlarged costs estimate regulations for construction industry that would allow calculating limit estimated costs. At the same time, during the first improvement phase for the system of enlarged costs estimate regulations in construction, main methodological caveats of costs formation in construction sector shall be indicated, along with possible solutions [19].

\section{Discussions}

Application of the organizational and economic mechanism for managing facility construction costs should be accompanied by development and implementation of a requirement managing system which represents an uninterrupted information and documentation-based process to guarantee results that correspond to requirements and expectations of end users for construction products: customers, contractors, vendors, and others [11]. The requirement management system shall be created and implemented in order to reduce expenditures related to the construction (upgrade, modernization, etc.) of a facility, transparency and flexibility of the facility costs management, which in turn, shall increase the customer's confidence that the works performed at the facility are being executed in accordance with project, regulatory technological, and other documentation, with due quality, in full scope and within the time limits [16-19].

Requirement managing system shall be built in compliance with the hierarchical interrelations of the process participants, which shall allow structuring and better describing 
all the requirements and the degree of their implementation accounting for the needs of the participants, but, first and foremost, of the customer, who, as of today, is formulating the requirements to the final product during the initial phase of the project. Nowadays, in construction sector, the customer specifies his needs and prepares a technical assignment that represents a certain initial list of requirements for the facility under construction at the planning phase. Technical assignment serves as the basis for requirement formation, accounting for facility life cycle phases, including hierarchical presentation of the complete requirements list, their analysis, specification, and approval [20].

All types of requirements might be classified into three groups. Functional requirements correspond to the result of each and every decision that is being taken. Restricting requirements distinguish properties or separate parameters that should be present in the solutions being applied. Organizational requirements, known as limitations, are determined by the mission, objective and driving forces of the company. At the same time, all the above requirements should be measurable and verifiable [8]

Development and implementation of a requirement managing system implies automatic data gathering and processing for control, reporting, main indicators' monitoring, correction of the managing decisions that have been applied. Thus, it is a certain instrument for displaying and registering various types of data obtained at different life cycle phases of a facility, in order to evaluate performance, progress stage, variability of effective requirements, efficiency of applied solutions, etc. Measurable indicators for registering and correcting the requirements shall allow controlling arising deviations from the preestablished limit values, thus justifying the necessity to revise the requirements due to their biased reflection of current situation. While gathering and analyzing information on managing facility construction costs during the project execution, the customer might make up his own information data base that would allow considerably improving quality, completeness, and coherence of his requirements [9].

\section{Conclusion}

Management of facility construction cost is an art of managing and coordinating human and material resources along the life cycle of the project through application of advanced management methods and techniques in order to achieve certain results in contents and scope of performed works, costs, terms, quality and overall satisfaction of the project participants. Successful execution of a project implies achieving target indicators while respecting the pre-established limitations in: costs, duration of production cycle, quality of performed works, and specific requirements to the facility construction. Besides, final result should be approved and accepted by the customer.

As of today, management of facility construction costs is unavailable both at the federal level and in the regions. There are some single attempts to implement managing components: switch to a new regulatory basis for costs estimates, development of regional price lists and information circulation letters, introduction of regulatory methodological documents, costs optimization during bidding process and making contracting agreements, application of software complexes and creation of information databases with costs indicators. From the development perspective, it is suggested to create a national information system for costs formation in construction that would correspond to the current requirements of a dynamic requirements. Efficiency of the proposed methods shall be ensured by increased accuracy of estimates at the phase of investment decision taking for any public capital investments, from direct budgetary expenditure to extra-budgetary funds resources, subsidies and grants. 


\section{References}

1. The official website of the Federal Service of State Statistics of the Russian Federation (2016), Information on: http://www.gks.ru/

2. The official website of the Concept of the Russian Federation pricing reform (2016), from: http://400days.ru/

3. I.I. Mazur, Investment and construction engineering: Textbooks for high schools (Elim, ZAO "Publishing House" Economics, Moscow, 2009)

4. I.V. Karakozova, Y.S. Prokhorova, Economy and Entrepreneurship, 3-2(56-2), 682$686(2015)$

5. V.R. Dorozhkin, The pricing and cost management in construction (Publisher by E.A.Bolhovitinova, Voronezh, 2003)

6. O.V. Didkovskaya, M.V. Ilina, O.A. Mamaeva, M.A. Konovalova, E.S. Spirina, Methodical approaches to formation of value engineering system in the building: monograph (Samara, 2013)

7. I.I. Mazur, V.D. Shapiro, N.G. Olderogge, A.Y. Zabrodin, Investment and construction engineering: Textbook (Elim, ZAO "Publishing house" Economy ", Moscow, 2009)

8. A.V. Tsvetkova, Total coast management. Translated from English, (Publishing House ZAO "PMSOFT", Moscow, 2013)

9. D. Tavassoli, Requirements management. Ten steps on the path to perfection. (2016), Information on: http://www.swd.ru/files/pdf/IBM_uspeh_edit1.pdf

10. The control system requirements (2016), Information on: http://www.diaprom.com/about/srm\#prettyPhoto

11. GOST R ISO / IEC 15288-2005 (2005) Information technology. Systems Engineering. The processes of the life cycle of systems. Approved and put into effect by order of the Federal Agency for Technical Regulation and Metrology of December 29, 2005 \# 476st.

12. Y.N. Kulakov, T.N. Silanteva, J. "Bulletin SWSU", 2 (2012)

13. A. J. Makin, Global Imbalances, Exchange Rates and Stabilization Policy (Palgrave Macmillan, Basingstoke, 2009)

14. A. Novoseltseva, Bulletin of the Volga. Episode 9: Studies of young scientists, 8-2 (2010)

15. V.I. Resin, The development of large cities in transition economies (systematic approach) (Editorial URSS, Moscow, 2000)

16. Russian Federation Government Decree dating from 02.02.2010. \# 102-P "On the approval of the concept of the federal target program "Complex program of modernization and reform of housing and communal services for 2010-2020"//the legislation bulletin of the Russian Federation. 2010 \# 7.

17. Sir P. Abercrombie, The Preservation of Rural England (Hodder and Stoughton Ltd, London, 1926)

18. E.N. Smirnov, Introduction to the world economy (economic geography of foreign countries) (KnoRus, Moscow, 2008)

19. E.M. Stein, Economics and Entrepreneurship, 3(2), 258-258 (2015)

20. N.G. Verstina, N.N. Taskaeva, Economics and Entrepreneurship, 8(37), 244-249 (2013) 